\title{
PENGGUNAAN MEDIA GAMBAR UNTUK MENINGKATKAN KETERAMPILAN MENULIS PARAGRAF DESKRIPSI SISWA SEKOLAH DASAR PEKANBARU
}

\author{
Siti Amaliyah, Zariul Antosa \\ Pendidikan Guru Sekolah Dasar FKIP Universitas Riau \\ Sitiamaliyah123@yahoo.com, zariul.antosa@lecturer.unri.ac.id
}

\begin{abstract}
ABSTRAK
Penelitian ini dilatar belakangi oleh rendahnya keterampilan menulis paragraf Deskripsi siswa kelas III SD Muhammadiyah 6 Pekanbaru, dari 22 orang siswa, hanya 8 orang siswa $(40 \%)$ yang terampil dan sisanya 12 orang siswa $(60 \%)$ kurang terampil. Penelitian ini adalah Penelitian Tindakan Kelas (PTK) yang dilakukan dalam 2 siklus setiap siklus terdiri dari 2 kali pertemuan. Penelitian ini bertujuan untuk meningkatkan keterampilan menulis paragraf deskripsi dengan penggunaan media gambar. Subjek penelitian ini adalah siswa kelas III SD Muhammadiyah 6 Pekanbaru. Data diperoleh melalui observasi dan tes. Teknik analisis data yang digunakan adalah teknik statistik deskriptif. Hasil penelitian menunjukkan bahwa persentase skor aktivitas guru pada siklus I sebesar $66,66 \%$, sedangkan pada siklus II persentase skor sebesar 91,66\%. Aktivitas siswa dalam pembelajaran juga mengalami peningkatan, aktivitas siswa pada siklus I persentase skor sebesar $66,66 \%$ sedangkan pada siklus II persentase skor sebesar $91,66 \%$. Hasil keterampilan menulis paragraf deskkripsi pada skor dasar rata-rata sebesar 65,3. Sementara itu, nilai keterampilan menulis paragraf deskripsi pada siklus I skor nilai rata-rata sebesar 87,2 , kemudian siklus II meningkat dengan rata-rata sebesar 89. Dari hasil penelitian ini maka dapat disimpulkan bahwa penggunaan media gambar dapat meningkatkan keterampilan menulis paragraf deskripsi siswa kelas III SD Muhammadiyah 6 Pekanbaru.
\end{abstract}

Kata Kunci : Media Gambar, Keterampilan Menulis Paragraf Deskripsi.

\section{ABSTRACT}

This research is based on the low skill of writing paragraph. Description of third grade students of primary school, from 22 students, only 8 students (40\%) are skilled and the remaining 12 students (60\%) are less skilled. This research is a Action Research conducted in 2 cycles per cycle consisting of 2 meetings. This study aims to improve the skills of writing description paragraphs with the use of image media. The subject of this research is the third grade students of primary school in Pekanbaru. Data obtained through observation and test. Data analysis technique used is descriptive statistical technique. The results showed that the percentage of teacher activity scores on the first cycle of $66.66 \%$, while in cycle II the percentage score of $91.66 \%$. Student activity in learning also experience improvement, student activity on cycle I score percentage equal to $6.66 \%$ whereas in cycle II percentage score equal to $91.66 \%$. The results of the writing skill of the descriptive paragraph on an average baseline score of 65.3. Meanwhile, the value of the writing skill of the description paragraph in the first cycle score average score of 87.2, then cycle II increased with an average of 89. It can be concluded 
that using image media can improve the skills to write paragraphs description of primary students.

Keywords: Image Media, Writing Skills Paragraph Description.

\section{PENDAHULUAN}

Mata pelajaran bahasa Indonesia adalah pembelajaran untuk mengembangkan pengetahuan, mempertinggi keterampilan berbahasa dan menumbuhkan sikap positif terhadap bahasa Indonesia. Dalam era globalisasi saat ini, penerapan ilmu pengetahuan dan teknologi harus didukung oleh sumber daya manusia yang berkualitas tinggi. Sebagai salah satu ilmu dasar, bahasa Indonesia telah berkembang pesat baik materi maupun kegunaannya. Namun sayang, sampai saat ini bahasa Indonesia dipandang sebagai mata pelajaran yang tidak penting, membosankan, dan tidak menyenangkan.

Pengajaran bahasa Indonesia dimaksudkan untuk meningkatkan kemampuan peserta didik untuk dapat berkomunikasi menggunakan bahasa Indonesia dengan baik dan benar, baik secara lisan maupun tulisan, serta menumbuhkan apresiasi hasil karya kesusastraan Indonesia. Keterampilan menulis merupakan salah satu keterampilan berbahasa yang juga harus diajarkan kepada siswa karena keterampilan menulis bukanlah keterampilan yang muncul secara spontan ataupun yang diturunkan secara turun temurun, tetapi membutuhkan suatu pelatihan yang rutin dan terus-menerus.

Keterampilan menulis diperlukan dalam berbagai bidang kehidupan. Menurut Hayon (2007) keterampilan berbahasa dibagi atas dua bagian utama yaitu keterampilan bahasa lisan dan keterampilan bahasa tulis. Keterampilan bahasa lisan terbagi atas dua, yaitu menyimak dan berbicara. Demikian pula, keterampilan tulis pun dibagi menjadi dua, yaitu membaca dan menulis. Berpedoman pada tujuan pengajaran bahasa Indonesia, maka bahasa Indonesia perlu diajarkan sejak seseorang memasuki pendidikan di jenjang Sekolah Dasar sampai perguruan tinggi. Pengajaran menulis permulaan sangat penting diajarkan di Sekolah Dasar agar anak-anak terlibat kegiatan baca tulis. Pembelajaran tersebut merupakan dasar menulis yang dapat menentukan murid Sekolah Dasar dalam menulis lanjut pada kelas berikutnya. Tanpa memiliki kemampuan menulis sejak dini, anak akan mengalami kesulitan belajar pada masa selanjutnya. 
Menulis merupakan kegiatan yang aktif dan produktif yang memerlukan cara berpikir teratur yang diungkapkan dalam bahasa tulis. Menulis yang dimaksud adalah sebagai keterampilan seseorang untuk menuangkan ide, pikiran, gagasan, pengetahun, ilmu, dan pengalaman, sehingga diperlukan suatu latihan dan praktik yang banyak dan teratur agar keterampilan menulis dapat tercapai. Menulis adalah kegiatan berbahasa yang menggunakan tulisan sebagai mediumnya. Pengembangan keterampilan menulis perlu mendapatkan perhatian yang sungguh-sungguh sejak pendidikan dasar sebagai aspek kemampuan berbahasa. Weaver (dalam Ida Bagus, 2015) mengklasifikasikan bentuk menulis menjadi lima, yaitu: narasi, deskripsi, eksposisi, argumentasi, dan persuasi. Paragraf deskripsi adalah paragraf yang menggambarkan suatu benda, tempat, suasana, keadaan dengan kata-kata. Keterampilan menulis paragraf deskripsi merupakan salah satu keterampilan menulis yang penting untuk dikuasai, karena melalui paragraf deskripsi seseorang dapat memberikan gambaran tentang suatu peristiwa atau kejadian Menulis paragraf deskripsi memeprlukan pengamatan yang tajam dengan semua alat inderanya, kemudian menuliskannya dengan katakata yang tepat atau dengan menggunakan perbandingan yang tepat.

Berdasarkan observasi dan dokumentasi peneliti dengan Rasmidia selaku guru wali kelas III SD Muhammadiyah 6 Pekanbaru, diketahui sebagian besar dari jumlah siswa kurang terampil dalam menulis paragraf deskripsi, untuk lebih jelasnya dapat dilihat pada tabel berikut:

Tabel 1

Data Awal Keterampilan Menulis Paragraf Deskripsi

\begin{tabular}{|c|c|c|c|c|c|}
\hline No & \multirow{2}{*}{$\begin{array}{c}\text { Jumlah } \\
\text { Siswa }\end{array}$} & $\begin{array}{c}\text { Sangat } \\
\text { Terampil }\end{array}$ & Terampil & $\begin{array}{c}\text { Cukup } \\
\text { Terampil }\end{array}$ & $\begin{array}{c}\text { Kurang } \\
\text { Terampil }\end{array}$ \\
\hline 1. & 22 & $\begin{array}{c}0 \\
(0 \%)\end{array}$ & $\begin{array}{c}3 \\
(15 \%)\end{array}$ & $\begin{array}{c}5 \\
(25 \%)\end{array}$ & $\begin{array}{c}12 \\
(60 \%)\end{array}$ \\
\hline
\end{tabular}

Berdasarkan tabel diatas dapat dilihat masih banyak siswa yang kurang terampil dalam menulis paragraf deskripsi hal ini disebabkan oleh beberapa faktot antara lain: 1) kurangnya minat siswa terhadap kegiatan menulis, 2) kurangnya motivasi siswa, baik dari dalam diri mereka maupuan dari lingkungan belajar, 3) pengembangan strategi pembelajaran yang kurang membangkitkan daya imajinasi siswa dan kreativitas siswa dalam berbahasa maupun bersastra, 4) tidak digunakannya media dalam pembelajaran sehingga siswa kurang bersemangat 
dalam belajar, 5) keterampilan siswa untuk menulis masih terbatas terlebih lagi untuk menulis paragraf deskripsi disebabkan karena pemahaman siswa terhadap keterampilan menulis masih kurang.

Pembelajaran hendaknya guru mampu memilih dan menggunakan strategi yang melibatkan keaktifan siswa dalam proses pembelajaran. Agar siswa belajar aktif, hendaknya pembelajaran mata pelajaran bahasa Indonesia dilakukan dengan menarik minat siswa, penggunaan metode yang tepat, media sebagai sarana yang efektif dalam menyampaikan pembelajaran walaupun sederhana. Untuk memperbaiki keterampilan menulis siswa perlu diterapkan suatu pembelajaran yang efektif sehingga dapat meningkatkan minat, motivasi, dan sikap terhadap pembelajaran menulis yang berakibat meningkatnya prestasi belajar siswa. Dengan demikian guru dapat merancang suatu bentuk pembelajaran langsung yang kreatif, efektif, dan menyenangkan melalui suatu media sebagai media alternatif dalam pemecahan masalah tersebut. Media berperan sebagai perangsang belajar dan dapat menumbuhkan motivasi belajar sehingga siswa tidak bosan dalam meraih tujuan-tujuan belajar.

Berdasarkan pemaparan dan permasalahan di atas, maka rumusan masalah dalam penelitian ini adalah apakah penggunaan media gambar dapat meningkatkan keterampilan menulis paragraf deskripsi di kelas III di SD Muhammadiyah 6 Pekanbaru? sehingga tujuan penilitian yang hendak dicapai adalah untuk meningkatkan keterampilan menulis paragraf deskripsi siswa kelas III SD Muhammadiyah 6 Pekanbaru dengan penggunaan media gambar.

\section{METODE PENELITIAN}

Penelitian Ini dilakukan di SD Muhammadiyah 6 Pekanbaru. Penelitian ini dilaksanakan pada semester II tahun 2016/2017. Subjek penelitian adalah siswa kelas III SD Muhammadiyah 6 Pekanbaru. Jumlah siswa kelas III adalah 22 orang, yaitu 11 orang siwa Perempuan dan 11 orang siswa Laki-laki.

Bentuk penelitian ini adalah penelitian tindakan kelas (PTK) dengan penggunaan media gambar untuk meningkatkan keterampilan menulis paragraf deskripsi siswa. Penelitian tindakan kelas secara garis besar terdapat empat tahap yang biasa dilalui yaitu: perencanaan, pelaksanaan, pengamatan, dan refleksi (Arikunto, 2008). Pelaksanaan tindakan dilakukan oleh peneliti dan guru 
kelas bertindak sebagai observer selama proses pembelajaran berlangsung dan melaksanakan refleksi disetiap akhir siklus. Instrumen dalam penelitian yaitu perangkat pembelajaran yang terdiri dari silabus, RPP, dan LKS, soal tes. Teknik pengumpulan data dalam penelitian ini adalah teknik observasi aktivitas guru/siswa dan tes keterampilan menulis paragraf deskripsi siswa.

Pelaksanaan aktivitas guru pada saat melakukan kegiatan belajar mengajar dikelas, untuk mengetahui kualitas proses guru dan siswa diamati oleh observer kemudian observer memberikan penlaian terhadap pelaksanaan

Tabel 2

Interval Aktivitas Guru dan Siswa

\begin{tabular}{|c|c|}
\hline Interval & Kategori \\
\hline $81-100$ & Sangat baik \\
$61-80$ & Baik \\
$51-60$ & Cukup \\
$\leq 50$ & Kurang \\
\hline
\end{tabular}

(sumber: dalam Syahrillfuddin, 2011)

Teknik analisis Keterampilan Menulis Paragraf Deskripsi siswa Untuk mengetahui keterampilan siswa dalam menulis paragraf deskripsi, peneliti menggunakan tes tertulis. Dalam hal ini Penulis membatasi indikator penilaian yaitu : (1) ketepatan isi paragraf, (2) diksi, (3) penggunaan ejaan, (4) kerapihan. Setiap aspek yang dinilai dengan skala 1 sampai 3 .

\section{Tabel 3}

Interval Keterampilan Menulis Paragraf Deskripsi

\begin{tabular}{|c|c|}
\hline Interval & Keterangan \\
\hline $86-100$ & Sangat terampil \\
$76-85$ & Terampil \\
$56-75$ & Cukup terampil \\
$10-55$ & Kurang \\
\hline
\end{tabular}

\section{HASIL PENELITIAN}

Untuk melihat keberhasilan tindakan, data yang diperoleh diolah sesuai dengan teknik analisis data yang ditetapkan. Selama proses pembelajaran berlangsung diadakan pengamatan terhadap aktivitas siswa dan guru. Berdasarkan pengamatan aktivitas siswa dan guru pada pertemuan pertama belum terlaksana sepenuhnya seperti yang direncanakan. Hal ini disebabkan siswa belum terbiasa menulis paragraf deskripsi dengan menggunakan media 
gambar. sedangkan pada pertemuan berokutnya aktivitas guru dan siswa mulai mendekati kearah yang lebih baik. peningkatan ini menunjukkan adanya keberhasilan pada setiap pertemuan. Data hasil observasi guru dapat dilihat pada tebel peningkatan aktivitas guru pada siklus I dan siklus II dibawah ini :

Tabel 4

Analisis Aktivitas Guru Siklus I dan Siklus II

\begin{tabular}{|c|c|c|c|c|}
\hline \multirow{2}{*}{ Aspek } & \multicolumn{2}{|c|}{ Siklus I } & \multicolumn{2}{|c|}{ Siklus II } \\
\hline & $\begin{array}{c}\text { Pertemuan } \\
\text { I }\end{array}$ & $\begin{array}{l}\text { Pertemuan } \\
\text { II }\end{array}$ & $\begin{array}{c}\text { Pertemuan } \\
\text { I }\end{array}$ & $\begin{array}{c}\text { Pertemuan } \\
\text { II }\end{array}$ \\
\hline Jumlah skor & 7 & 8 & 10 & 11 \\
\hline Persentase & $58,33 \%$ & $66,66 \%$ & $83,33 \%$ & $91,66 \%$ \\
\hline Kategori & Cukup & Baik & $\begin{array}{c}\text { Sangat } \\
\text { baik }\end{array}$ & $\begin{array}{l}\text { Sangat } \\
\text { baik }\end{array}$ \\
\hline
\end{tabular}

Tabel di atas menunjukkan bahwa pada pertemuan I aktivitas guru dengan skor 7 dengan presentase (58,33\%) dikategorikan cukup, pada pertemuan II skor 8 dengan presentase (66,66\%) dikategorikan baik. Sedangkan pada siklus II pertemuan I dengan skor 10 dengan presentase (83,33\%) dengan kategori sangat baik, dan pertemuan II dengan skor 11 dengan presentase $(91,66 \%)$ dengan kategori sangat baik. Disiini terjadi peningkatan aktivitas guru pada setiap pertemuannya, hal ini disebabkan guru telah memahami dan menguasai komponen menulis paragraf deskripsi serta telah melaksanakan penggunaan media gambar.

Tabel 5

Analisis Aktivitas Siswa siklus I dan Siklus II

\begin{tabular}{|c|c|c|c|c|c|}
\hline \multirow[b]{2}{*}{ No } & \multirow{2}{*}{ Aspek } & \multicolumn{2}{|c|}{ Siklus I } & \multicolumn{2}{|c|}{ Siklus II } \\
\hline & & $\begin{array}{c}\text { Pertemuan } \\
\text { I }\end{array}$ & $\begin{array}{c}\text { Pertemuan } \\
\text { II }\end{array}$ & $\begin{array}{c}\text { Pertemuan } \\
\text { I }\end{array}$ & $\begin{array}{c}\text { Pertemuan } \\
\text { II }\end{array}$ \\
\hline $\begin{array}{l}1 . \\
2 \\
3 .\end{array}$ & $\begin{array}{l}\text { Jumlah } \\
\text { skor } \\
\text { Persentase } \\
\text { Kategori }\end{array}$ & $\begin{array}{c}6 \\
50 \% \\
\text { kurang }\end{array}$ & $\begin{array}{c}8 \\
66,66 \% \\
\text { Baik }\end{array}$ & $\begin{array}{c}9 \\
75 \% \\
\text { Baik }\end{array}$ & $\begin{array}{c}11 \\
91,66 \% \\
\text { Sangat baik }\end{array}$ \\
\hline
\end{tabular}

Tabel di atas menunjukkan bahwa pada pertemuan I siklus I aktivitas siswa dengan skor 6 dengan presentase (50\%) dengan kategori kurang, pada pertemuan II skor 8 dengan presentase $(66,66 \%)$ dikategorikan baik. Sedangkan pada siklus II pertemuan I aktivitas siswa dengan skor 9 dengan presentase (75\%) dengan kategori baik, pada pertemuan II dengan skor 11 dengan presentase 
$(91,66 \%)$ dikategorikan sangat baik. disini terjadi peningkatan aktivitas siswa pada setiap pertemuannya hal ini disebabkan siswa telah memahami dan menguasai komponen dan penggunaan media gambar dalam menulis paragraf deskripsi.

\section{Hasil Keterampilan Menulis Paragraf Deskripsi}

Hasil keterampilan menulis paragraf deskripsi ditentukan berdasarkan hasil ulangan akhir siklus I (UH I) dan ulangan akhir siklus II (UH II) dapat dilihat pada tabel berikut:

Tabel 6

Hasil skor dasar keterampilan menulis paragraf deskripsi

\begin{tabular}{|c|c|c|c|c|}
\hline Data & Interval & Rata-rata & $\begin{array}{c}\text { Siswa yang } \\
\text { tuntas }\end{array}$ & Keterangan \\
\hline \multirow{3}{*}{ SD } & $86-100$ & \multirow{2}{*}{65,3} & 0 & Sangat \\
& $76-85$ & & 3 & Trampil \\
& $56-75$ & & 5 & Trampil \\
& $10-55$ & & 12 & Cukup trampil \\
& & & 20 & \\
\hline
\end{tabular}

Tabel di atas menunjukkan bahwa hasil keterampilan menulis paragraf deskripsi sebelum tindakan dengan jumlah siswa 20 orang siswa dengan siswa sangat terampil tidak ada, 3 siswa terampil, 5 orang siswa cukup terampil dan 13 orang siswa kurang terampil, dengan jumlah rata-rata semua yaitu 65,3. Dari dari data tersebut dapat disimpulkan bahwa sebagian besar siswa masih kurang terampil dalam menulis paragraf deskripsi.

Tabel 7

Hasil keterampilan menulis paragraf deskripsi pada siklus I

\begin{tabular}{|c|c|c|c|c|}
\hline Data & Interval & $\begin{array}{c}\text { Rata- } \\
\text { rata }\end{array}$ & $\begin{array}{c}\text { Jumlah } \\
\text { siswa }\end{array}$ & Keterangan \\
\hline \multirow{3}{*}{ UH I } & $86-100$ & & 10 & Sangat Terampil \\
& $76-85$ & 87,2 & 4 & Terampil \\
& $56-75$ & & 4 & Cukup terampil \\
& $10-55$ & & 2 & Kurang terampil \\
\hline \multicolumn{2}{|c|}{ Jumlah siswa } & 22 & \\
\hline
\end{tabular}

Tabel di atas menunjukkan bahwa hasil keterampilan menulis paragraf deskripsi setelah tindakan penggunaan media gambar dengan jumlah siswa 20 orang siswa dengan 10 orang siswa sangat terampil, 4 orang siswa terampil, 4 orang siswa cukup terampil dan 2 orang siswa kurang terampil dengan jumlah 
rata-rata nilai 87,2 . Dari hasil keterampilan diatas dapat disimpulkan bahwa dalam keterampilan menulis paragraf deskripsi mengalami peningkatan dibandingkan dengan skor dasar namun, masih ada beberapa siswa yang kurang terampil dalam menulis paragraf deskripsi.

Tabel 8

Hasil keterampilan menulis paragraf deskripsi pada siklus II

\begin{tabular}{|l|c|c|c|c|}
\hline Data & Interval & $\begin{array}{c}\text { Rata- } \\
\text { rata }\end{array}$ & Jumlah Siswa & Keterangan \\
\hline \multirow{3}{*}{ UH II } & $86-100$ & & 11 & Sangat Trampil \\
& $76-85$ & 89 & 6 & Trampil \\
& $56-75$ & & 3 & Cukup trampil \\
& $10-55$ & & 0 & Kurang trampil \\
\hline \multicolumn{3}{|c|}{ Jumlah siswa } & 22 & \\
\hline
\end{tabular}

Tabel di atas menunjukkan bahwa hasil keterampilan menulis paragraf deskripsi dengan penggunaan media gambar pada siklus II dengan jumlah siswa 20 orang siswa dengan 11 orang siswa sangat terampil, 6 orang siswa terampil, 3 orang siswa cukup terampil dan 0 orang siswa kurang terampil dengan jumlah rata-rata nilai 89. Dari hasil keterampilan pada siklus II tabel diatas dapat disimpulkan bahwa sebagian besar siswa sudah sangat terampil dalam menulis paragraf deskripsi dengan menggunakan media gambar.

\section{Tabel 9}

Rekapitulasi Peningkatan Keterampilan Menulis Paragraf Deskripsi dengan menggunakan Media Gambar sesuai dengan Keterangan

\begin{tabular}{|l|c|c|c|c|c|}
\hline No & Interval & SD & UH I & UH II & Kategori \\
\hline 1. & $92-100$ & 0 siswa & 10 siswa & 11 siswa & Sangat Trampil \\
2. & $84-91$ & 3 siswa & 4 siswa & 6 siswa & Trampil \\
3. & $76-83$ & 5 siswa & 4 siswa & 3 siswa & Cukup trampil \\
4. & $\leq 75$ & 12 siswa & 2 siswa & 0 siswa & Kurang trampil \\
\hline \multicolumn{2}{|l|}{ Jumlah siswa } & \multicolumn{3}{|c|}{20} \\
\hline
\end{tabular}

Tabel di atas menunjukkan bahwa peningkatan keterampilan menulis paragraph deskripsi dari sebelum dilakukan tindakan dan setelah dilakukannya tindakan terjadi peningkatan pada setiap siklusnya. Hal ini dapat disimpulkan bahwa penggunaan media gambar dapat meningkatkan keterampilan menulis paragraf deskripsi siswa kelas III SD Muhammadiyah 6 Pekanbaru. 


\section{PEMBAHASAN HASIL PENELITIAN}

Setelah dilaksanakannya tindakan perbaikan pembelajaran dengan menggunakan media gambar hasilnya meningkat, hal ini terlihat pada peningkatan kualitas aktivitas guru dan siswa. Keterampilan siswa dalam menulis paragraf deskripsi ditandai dengan meningkatnya skor rata-rata keterampilan menulis paragraf deskripsi. Meningkatnya keterampilan menulis paragraf deskripsi siswa kelas III disebabkan karena penggunaan media gambar, sehingga siswa lebih bersemangat dalam menerima pelajaran. Menurut Rusman (Agung Nuroho, 2014) media gambar adalah pengantar pesan antara pengirim dan penerima pesan yang diwujudkan secara visual kedalam bentuk dua dimensi sebagi hasil pikiran dan perasaan, selain itu gambar juga dapat menimbulkan daya tarik pada diri siswa, mempermudah pengertian dan memperjelas bagian bagian penting yang kan ditulis. Media gambar mampu memberikan kepada gambaran sesuatu yang nyata, sehingga mampu mengantarkan imajinasi siswa kepada sesuatu proses sesungguhnya terjadi dan memudahkan siswa menuangkan ide.

Pada observasi aktivitas guru dengan menggunakan media gambar mengalami peningkatan setiap kali pertemuan. Dapat dilihat pada persentase aktivitas guru yaitu siklus I pertemuan pertama dengan persentase 58,33\% dengan kategori cukup, dan pertemuan kedua dengan persentase 66,66\% dengan kategori baik. kemudian pada siklus II pertemuan pertama dengan nilai 83,33\% dengan kategori sangat baik dan pertemuan kedua dengan persentase $91,66 \%$ dengan kategori sangat baik. Hal ini guru semakin mengerti bagaimana cara mengajar penggunaan media gambar dalam proses pembelajaran dan guru semakin bisa mengontrol dalam pembelajaran.

Pada observasi aktivitas siswa dalam penggunaan media gambar juga mengalami peningkatan setiap kali pertemuan. Pada pertemuan pertama siklus I dengan persentase $50 \%$ dengan kategori kurang dan pada pertemuan kedua sebanyak 66,66\% dengan kategori baik. pada siklus II pertemuan pertama aktivitas siswa meningkat lagi sebanyak $75 \%$ dengan kategori baik dan pertemuan kedua persentasenya sebanyak $91,66 \%$ dengan kategori sangat baik. Dengan meningkatnya aktivitas guru maka siswa akan termotivasi dalam proses pembelajaran. Jika siswa termotivasi maka siswa akan aktif dan mendengarkan dengan baik materi yang disampaikan guru, dapat dilihat pada proses 
pembelajaran berlangsung sebagian besar siswa bersemangat dan aktif dalam mengerjakan tugas. Secara keseluruhan aktivitas siswa semakin meningkat pada tiap pertemuan dengan menggunakan media gambar.

Rendahnya nilai siswa pada skor dasar dimana siswa dalam menulis paragraf deskripsi hal ini dapat dilihat siswa yang sangat terampil tidak ada, 3 orang siswa terampil, 5 orang siswa cukup terampil dan 12 orang siswa kurang terampil, dengan rata-rata nilai 65,3 . Hal ini karena belum digunakannya media gambar dalam pembelajaran sehingga siswa sulit untuk memulai atau menuangkan ide dalam menulis paragraf deskripsi. Oleh karena itu peneliti menggunakan media gambar untuk memotivasi siswa dalam mengembangkan ide atau gagasan siswa dalam menulis paragraf deskripsi. Kemudian pada siklus I hasil keterampilan menulis paragraf deskripsi dengan menggunakan media gambar mengalami peningkatan dibanding dengan skor dasar. Dapat dilihat dari hasil ulangan harian siklus I bahwa siswa yang sangat terampil 10 orang siswa, 4 orang siswa terampil, 4 orang siswa cukup terampil dan 2 orang siswa kurang terampil dengan rata-rata nilai 87,2. Dari sebagian siswa ada beberapa siswa yang masih kurang terampil hal ini disebabkan siswa belum terlatih dan belum terbiasa menuangkan idenya. Demikian juga dalam aspek pemilihan kata belum terlatih dengan baik dikarenkan siswa masih memiliki rasa malu kurang berani dan kurang percaya diri dan kemampuan siswa mengamati gambar masih kurang cermat dan teliti selain itu baru pertama kalinya digunakannya media gambar sebagai pembelajaran dikelas khususnya menulis paragraf deskripsi. Selanjutnya pada siklus II hasil keterampilan menulis paragraf deskripsi dengan menggunakan media gambar mengalami peningkatan dibanding dengan skor rata-rata siklus I dapat dilihat dari hasil ulangan harian siklus II siswa yang sangat terampil 11 orang siswa, 6 orang siswa terampil, 3 orang siswa cukup terampil dan 0 orang siswa kurang terampil dengan rata-rata nilai 89. Peningkatan ini terjadi karena siswa sudah mulai terbiasa dalam penggunaan media gambar dalam menulis paragraf deskripsi yang diterapkan oleh guru, hal ini terlihat siswa sudah aktif dalam mengerjakan tugasnya. Guru juga sudah terbiasa dalam menerapkan penggunaan media gambar dan menguasai kelas dengan baik.

Pembelajaran dengan menggunakan media gambar dapat menarik perhatian siswa sehingga menumbuhkan motivasi belajar, bahan pengajaran akan 
lebih jelas maknanya sehingga dapat dipahami oleh siswa dan memungkinkan menguasai dan tercapainya tujuan pembelajaran. Berdasarkan pembahasan diatas, dapat disimpulkan bahwa penggunaan media gambar dapat meningkatkan keterampilan menulis paragraf deskripsi siswa kelas III SD Muhammdiyah 6 Pekanbaru.

\section{SIMPULAN DAN SARAN}

\section{Simpulan}

Berdasarkan hasil analisis dalam pembahasan ini dapat ditarik beberapa kesimpulan sebagai berikut: Penggunaan media gambar dapat meningkatkan keterampilan menulis paragraf deskripsi siswa kelas III SD Muhammadiyah 6 Pekanbaru. Hal ini terbukti dari hasil ulangan yang dilakukan pada siklus I dengan rata-rata nilai 87,2. Sedangkan pada siklus II rata-rata nilai siswa mencapai 89 . Kondisi ini menunjukkan adanya peningkatan dari siklus I ke siklus II. Penggunaan media gambar dapat meningkatkan aktivitas guru dalam proses pembelajaran yang berlangsung. Hal ini dapat dilihat dari hasil observasi aktivitas guru pada pertemuan pertama siklus I persentase sebesar 58,33\% lalu pada pertemuan kedua siklus I meningkat menjadi $66,66 \%$. Pada pertemuan pertama siklus II aktivitas guru menjadi $83,33 \%$ dan pada pertemuan kedua siklus II meningkat lagi menjadi $91,66 \%$. Penggunaan media gambar juga terbukti dapat meningkatkan aktivitas siswa. Hal ini dapat dilihat dari hasil observasi yang menunjukkan bahwa aktivitas siswa meningkat pada setiap siklusnya. Pada pertemua pertama siklus I persentasenya sebesar $50 \%$ lalu pada pertemuan kedua siklus I meningkat menjadi $66,66 \%$. Pada pertemuan pertama siklus II persentase aktivitas siswa $75 \%$ dan pada pertemuan pertama siklus II meningkat menjadi 91,66\%. Jadi kondisi ini menujukkan adanya peningkatan dari siklus I ke siklus II.

\section{Saran}

Rekomendasi penelitian ini ialah peneliti mengajukan beberapa saran yang berhubungan dengan penerapan penggunaan media gambar dalam pembelajaran, yaitu: Bagi guru dan sekolah penggunaan media gambar dapat dijadikan sebagai salah satu alternatif dalam pembelajaran bahasa Indonesia khususnya menulis paragraf deskripsi guna meningkatkan keterampilan menulis, guru harus mampu untuk menciptakan situasi yang menarik dalam proses belajar 
mengajar. Guru juga harus memberikan sebuah variasi dari media didalam mengajar mengapresiasi materi pelajaran. Jadi siswa harus aktif dan tertarik dalam mengikuti proses belajar mengajar, peneliti merekomendasikan untuk menggunakan media gambar untuk mengajar dalam menulis paragraf deskripsi. Peneliti berharap bahwa hasil dari penelitian ini akan meberikan nilai kontribusi untuk pembaca.

\section{DAFTAR PUSTAKA}

Azhar, Arsyad. 2002. Media Pembelajaran. PT RajaGrafindo Persada: Jakarta.

Burhan, Nurgiantoro. 2014. Penilaian Pembelajaran Bahasa Berbasis Kompetensi. BPFE-Yogyakarta: Yogyakarta.

Dadan, Djuanda. 2006. Pembelajaran Bahasa Indonesia Yang Komunikatif dan Menyenangkan. Depdiknas: Jakarta.

Dalman. 2011. Keterampilan Menulis. PT Raja Grafindo Persada: Jakarta.

Isma Afriyanti. 2012. Penggunaan Media Gambar Untuk Meningkatkan Aktivitas Dan Hasil Belajar Siswa Pada Mata Pelajaran IImu Pengetahuan Alam di Sekolah Dasar Negeri. FKIP Universitas Tanjungpura: Pontianak.

Ida, Agus Putrayasa. 2015. Pembelajaran Menulis Paragraf Deskripsi Berbasis Mind Mapping Pada Siswa Kelas VII SMP Laboratorium Andiksha

Sadiman, Arief S. dkk. 2003. Media Pendidikan Pengertian, Pengembangan dan Pemanfaatannya. PT RajaGrafindo Persada: Jakarta.

Sri Hapsari wijayanti, dkk. 2013. Bahasa Indonesia Penulisan dan Penyajian karya Ilmiah. PT RajaGrafindo Persada. Jakarta

Suharsimi Arikunto. 2008. Penelitian Tindakan Kelas. PT Bumi Aksara: Jakarta.

Syahrillfuddin, dkk. 2011. Penelitian Tindakan Kelas. Cendikia Insani. Pekanbaru. Tarigan Djago. 2008. Membina Keterampilan Menulis Paragraf Dan Pengembangannya. Angkasa: Bandung.

Zainal Aqib dkk. 2011. Penelitian Tindakan Kelas Untuk Guru SMP, SMA, SMK. Yrama Widya. Bandung. 